\title{
Mother Tongue Use in Task-Based Language Teaching Model
}

\author{
Nguyen Viet Hung ${ }^{1}$ \\ ${ }^{1}$ Faculty of Postgraduate Studies at University of Languages and International Studies, Vietnam National \\ University, Hanoi, Vietnam \\ Correspondence: Nguyen Viet Hung, PhD Student of ELT Methodology, Faculty of Postgraduate Studies at \\ University of Languages and International Studies, Vietnam National University, Hanoi, Vietnam. Tel: \\ 84-972-862-865/84-904-810-638. E-mail: nguyenviethungvnu@gmail.com
}

\author{
Received: April 25, 2012 Accepted: May 10, 2012 Online Published: June 28, 2012 \\ doi:10.5539/elt.v5n8p23 URL: http://dx.doi.org/10.5539/elt.v5n8p23
}

\begin{abstract}
Researches of English language teaching (ELT) have focused on using mother tongue (L1) for years. The proliferation of task-based language teaching (TBLT) has been also occurred. Considerable findings have been made in the existing literature of the two fields; however, no mentions have been made in the combination of these two ELT aspects, i.e., the use of L1 in English as a Second and Foreign Language (L2) classrooms in which TBLT is adopted. Hence, this paper is to make an argumentation in the appropriateness of this combination. Firstly, terminologies related to Tasks and TBLT framework are shortly revised. Secondly, the controversies with for and against views in monolingual approach in second and foreign language teaching (L2 teaching) is mentioned. Lastly, the paper makes an argumentation on why and how to use mother tongue in a modern teaching model as TBLT.
\end{abstract}

Keywords: ELT, TBLT, L1, L2, monolingual approach

\section{Introduction}

TBLT has been known for years as a teaching instruction model with a lot of benefits, and it has attracted much attention of ELT teachers since it is the realization of CLT as a branch (Lee, 2000; Willis \& Willis, 2001; Carless, 2003; Richards Frost, 2006). Theoretical issues, such as, framework of instruction, task design, Task-based syllabus design has been researched worldwide, and publications on this field bloomed violently (the works of Prabu, 1987; Bygate, 2001; Ellis, 2005; Lee, 2000; Long, 2005; Nunan, 200; Skehan, 1996, 2003; Willis, 1996). In addition, practical issues of a teaching have been studied to help teachers get over their problems in their classrooms (see Carless, 2003, 2007; Littlewood, 2004, 2007, etc.). Despite TBLT is used for English learning and teaching of international students with their own native languages, no mention has made to answer the need of ELT teachers that whether mother tongue can be used in TBLT model in classroom teaching practice or not. Therefore, this paper, one in series of papers related to ELT quality in secondary schools in Vietnam since when the implementation of new series of English textbooks has officially been passed (2006) with the innovated direction paid towards $\mathrm{TBLT}^{(1)}$, provides a small effort to bridge the gap in the theoretical issue. The argumentation will start from approvals of L1 in L2 classrooms and then show out the fits of L1 in different phases of TBLT model.

\section{Task-Based Language Teaching}

\subsection{Notion of Tasks and TBLT}

The definition of task has been very various in the literature (e.g., Prabu, 1987; Bygate, 2001; Ellis, 2000, 2003, 2005; Lee, 2000; Long, 1985, 1991, 1997, 2005; Nunan, 2003, 2004a; Richards and Rodgers, 2001; Salaberry, 2001; Skehan, 1996, 1998a, 1998b, 2003; Willis, 1996, 1998, 2001). In adequateness of this small section, some of the notions popular in literature and familiar with Willis (1996) - the chosen TBLT model for the textbooks of English at secondary schools are revised. Prabhu (1987), one of the first methodologists raising interest and support for TBL, considers a task is "an activity which required learners to arrive at an outcome from given information through some process of thought, and which allowed teachers to control and regulate that process". He credited that the task-based teaching and learning is a good way of education and language practice as effective learning occurs when students are fully engaged in a language task, rather than just learning about language (p. 17). Lee (2000) defines a task is "(1) a classroom activity or exercise that has: (a) an objective 
obtainable only by interaction among participants, (b) a mechanism for structuring and sequencing interaction, and (c) a focus on meaning exchange; (2) a language learning endeavor that requires learners to comprehend, manipulate, and/or produce the target language as they perform some sets of work plans" (p. 32). Bygate, Skehan, and Swain (2001) view 'A task is an activity which requires learners to use language, with emphasis on meaning, to attain an objective'. More circumscribed is the following from Willis (1996), cited in Willis and Willis (2001): a classroom undertaking ". . . where the target language is used by the learner for a communicative purpose (goal) in order to achieve an outcome". Here the notion of meaning is subsumed in 'outcome'. Language in a communicative task is seen as bringing about an outcome through the exchange of meanings (p. 173).

Aforementioned definitions vary somewhat, they all emphasize the fact that pedagogical tasks involve communicative language use in which the user's attention is focused on meaning rather than grammatical form. However, this does not mean that form is not important. My own view of a pedagogical task is strongly influenced by Willis (1996) and Lee (2000), which is: task-based language teaching is the implementation of pedagogical tasks inspired from the real world tasks, fitted well to students' need and interest, and socially contextualized in the direction of strong form realization of CLT. A task, as the basis for teaching and learning, is goal-oriented, meaning-focused first and form-focused then, and is implemented by students with a clear procedure or mechanism in combination with enough authentic and comprehensible input. The task doing is through interactions (in pairs or in small groups) in which their own experiences of target language are exploited, and lastly access the completeness through the outcome.

\subsection{Framework for TBLT}

TBLT framework is in fact the favorable way to sequence tasks or to sequence elements within tasks proposed by researchers and methodologists. As noted by Richards and Rodgers (2001), sequencing is a major issue in a task-based syllabus. There are several frameworks in literature, such as the framework from Jane Willis (1996), Long (1985, 1991, 1997, 2005), Johnson (1996), Skehan (1996, 1998b), Salaberry (2001), Ellis (2003), Nunan (2003, 2004), Richards Frost (2006). However, for the properness of this section, I only mention the framework of Willis (1996) as it is popular model, and is advocated much in literature. More importantly and purposefully, this model is the chosen one for the English textbooks of secondary schools in Vietnam. The model is presented in the following figure:

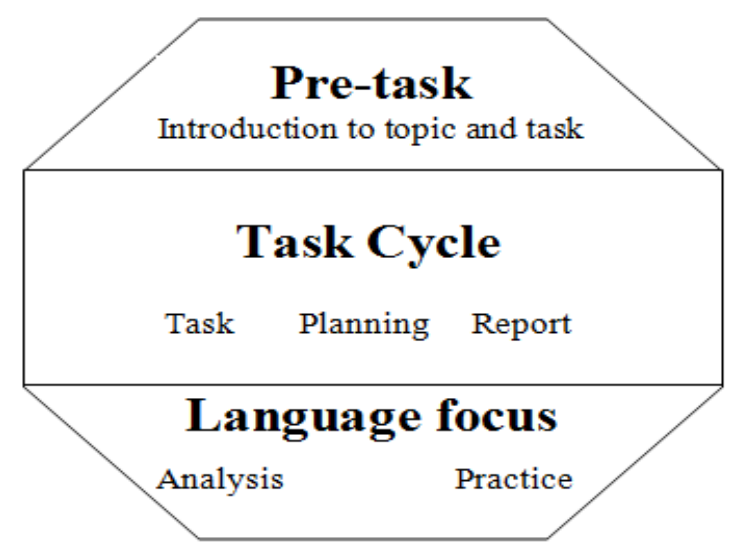

Figure 1. TBL Framework by Willis

As can be seen, Jane Willis $(1996,1998)$ designed precisely the framework for TBLT, which was then advocated by Richards Frost (2006) including three main phases, i.e. preparation for the task (pre-task), the task itself (task-cycle), and follow-up or language focus (post-task). In addition, tasks are often placed into a sequence as part of a unit of work or study. Many second language learner textbooks now follow this practice. Pre-task phase is when teacher introduce topic and task, and students get exposures of linguistic chunks and any need of comprehensive input. The task cycle can be subdivided into three task stages, including task stage, planning stage, and report stage. This is the main task phase in which students use the target language the most to accomplish task requirements to get the task objectives; the fluency and meaning-focus is main attended. In this phase teacher's support of linguistic chunks or task doing skill is necessary at any time students have troubles or insufficiencies. The last phase is language focus, in which teacher, basing on what learners have done in the previous phase, helps learners to enrich linguistic items with more focus on accuracy. 


\section{Controversies in Using Mother Tongue}

The use of student's mother tongue in ELT classrooms has continually been one of debatable issues when the ELT methodology underwent through a long history, from very traditional conventions to today practices (Gatenby, 1965; Auerbach, 1993; Seidlhofer, 1999; Richards, 1992; Crookes \& Gass, 1993; Polio, 1994; Burden, 2000; Brown, 2001; Paradis, 2004). The confliction occurs in two opposite ways, that is, (1) If L1 is used in language teaching, learners will become dependent on L1, and not even try to understand meaning from context and explanation, or express what they want to say within their limited command of the target language (L2), (2) A non-threatening environment is essential for L2 learners to learn the target language effectively and so L1 can be used by the teacher to some extent. The monolingual approach in L2 teaching has been common in ELT methodology with many controversies between two extremes, advocating view and protesting view.

Advocators for the monolingual approach of L2 to the teaching of English could hold the view that the teaching of English as a foreign and a second language should be completely through the target language (Gatenby, 1965; Long, 1985; Richards, 1992; Philipson, 1992; Crookes \& Gass, 1993; Polio, 1994; Cross, 1995; Nunan 1995; Johnson, 1996; Brown, 2001; Bygate, 2001) because "the language being studied should be as far as possible the sole medium of communication in any given environment (Gatenby, 1965, p.14). In ELT classrooms, thus, the only language allowed in the classroom is English. The hidden belief after this viewpoint may be that the exclusive focus on the target language will maximize the language learning (Phillipson, 1992; Nunan, 1992, 1995. 1999; Brown, 2001). In other words, the avoidance of L1 or any other languages could descend from a belief that other languages are a hindrance in foreign language learning.

Opponents, in an opposite thought, have supposed that the monolingual approach should be perceived in a more critical manner (Widdowson, 1974; Atkinson, 1987; Anton \& DiCamila, 1998; Swain and Lapkin, 1998; Seidlhofer, 1999; Wells, 1999; Burden, 2000; Tang, 2002; Marian, 2003; Marian, Spivey, \& Hirsch, 2003; Paradis, 2004). There have been lots of protests of monolingual approach (only L2 in English classrooms) in Asian context, and the prejudiced notion of mother tongue use in CLT classrooms in teaching context Asian countries should be revaluated since the application is much different from Western countries where these teaching methods originated (Pham, 2001; Canh, 2001; Phan, 2008). TBLT, the teaching model of the English textbooks in Vietnam, is no exception in that context. According to Seidlhofer (1999) and Burden (2000), the reasons for ELT teachers from English-speaking countries and book designers from these countries want interactions in L2 classrooms to be in English may depend on the fact that native speaker teachers (L2) without the need of knowing their students' language (L1) and culture can be easier going all over the world to get jobs as English teachers. Another reason why the monolingual approach should be re-evaluated is the fact that research in second language acquisition (SLA) indicates that bilingualism is an advantage, not a hindrance, for language learners. As Cook (2001) notes, "people who know two languages think more flexibly than monolinguals" (p. 10). Teachers' discourage to their students from L1 use in ELT classrooms implicitly ignores the fact.

\section{Why and How to Use Mother Tongue in Task-Based Language Teaching Model?}

The claims of L1 use from their students are not down in a lot of teachers' minds, and there are high controversies in this problem in Vietnam. We know that all the changes and innovations mentioned above is to foster students' ability of communication, not to whether reduce students' mother tongue use or not. The application of TBLT framework in ELT at secondary schools is no exception. Thus, why shall we focus on the main aim rather than the side effect? And why should we not think if mother tongue can urge the development of students' communicative ability, it can be allowed in a proper amount? All of those main issues above will be presented and discussed in this section.

\subsection{Reasons for the Application of Mother Tongue in TBLT Model}

As can be seen from figure 1 and the concept of TBLT, the main focus of teaching and learning is the task completion to get the goals; language is only the tool to serve the task. Therefore, the support of teachers in the role of input and scaffolding provision should not cause the interruption of task cycle. To these types of communicative tasks in TBLT model, the L1 use may act its role for the benefit of task doing. Generally in ELT and particularly in TBLT model, the use of mother tongue has clear advantages that I will in turn demonstrate as below.

Firstly, mother tongue can enable students' understanding of the concepts, lexical or grammatical or academic terms, etc. No other means rather than their mother tongue can ensure the correct shape of a particular concept (Marian \& Spivey, 2003; Marian, Spivey, \& Hirsch, 2003). The reason is that in people who have acquired a L2 after the sensitive period for language acquisition, it appears that the two languages access a common semantic 
system (Marian \& Spivey, 2003; Marian, Spivey, \& Hirsch, 2003). For example, English tenses are the most troublesome for almost Vietnamese learners since L1 does not have them; therefore, the teachers' explanation elsewhere in their teaching as a way of providing scaffolding or input is needed, and the requirement of their students' explanation in Vietnamese can indicate their understanding of the concept.

Secondly, the overuse of the mother tongue by the students may also reveal that a given task or the teachers' explanation may be too difficult, not clear, not interesting or too confusing, so it is time-efficient in teachers' perceptions of class situations (Cook, 2001; Wells, 1999).

Next, the use of L1 may be time-saving in the teachers' provision of lexical and grammatical input for the interaction to be ongoing to the end of task completion. At this case, there is no need demonstrating and English word or item especially abstract ones for a long time, a quick and accurate translation is enough since this decision can keep the task doing uninterrupted and keep students persisted to the task. Swain \& Lapkin (1998) incidentally found that the L1 was a "mediational tool fully available to learners, to regulate their own behavior, to focus attention on specific L2 structures, and to generate and assess alternatives" (p. 333). Moreover, an explanation of words or items in the target language does not lead to the correct understanding of students.

In addition, when teachers and students have the same mother tongue and share a similar linguistic and cultural background, there are good reasons for using translation as it would be consistent with the general educational maxim of social constructivism that learning involves the construction of new knowledge based on the familiar one called the zone of proximal development proposed by Vygotsky (Seidlhofer, 1999; Cook, 2001). Seidlhofer (1999) further explains that

Translation relates the language to be learnt to the linguistic experience that people have already had, and this of course can reduce a good deal of the threat of the new subject, and help the learner to appropriate the new language. It is entirely natural to seek to make new experience meaningful by referring it to conceptual categories drawn from previous experience, and so translation is, in this respect, the reflex of natural learning. (Seidlhofer, 1999, p. 240)

Besides, research findings from Auerbach (1993), and Storch and Wigglesworth (2003) declared that the use of the L1 could reduce anxiety and foster the affective environment for learning according to Krashen's Affective Filter Hypothesis, an imaginary barrier which prevents learners from acquiring language. Lightbown and Spada (1999) gives out examples of 'affective factors' as motives, needs, attitudes, and emotional states. The best situations for language learning are those which provide lower anxiety levels (Lightbown \& Spada, 1999, p. 39). Atkinson (1987), Harbord (1992) and Tang (2002) points out that the use of the mother tongue can encourage hesitant, frightened, or nervous students to participate in learning activities as it will put students at ease. In short, the use of mother tongue helps to create a less threatening atmosphere.

Lastly, the bilingual uses of languages can enable the understanding between languages in communication. Paradis (2004) states that "there is no evidence that the languages of bilinguals are each represented in a different locus in the brain. Both language systems seem to be represented as distinct microanatomical subsystems located in the same gross anatomical areas." (p. 116).

\subsection{Ways of Mother Tongue Use in TBLT Model}

As the suggestions of methodologists (Atkinson 1987, Auerbach 1993, and Cook 2001), the use of mother tongue in ELT classrooms should be selective. It means the overuse of L1 must be excluded. Tang (2002) put that teachers often use L1 in beginning and intermediate classes to: (1) give instructions, (2) explain meanings of words, (3) explain complex ideas, and (4) explain complex grammar points. Storch \& Wigglesworth (2003) found that when students used their shared L1, they reported that it was useful for task management, task clarification, determining meaning and vocabulary, and explaining grammar. Hence, the question "How should teachers use L1 to urge students' learning? Put it in another way, in what cases can teachers use L1 to foster the interactions of students in their problem-solving communicative tasks?" is in need of being clarified.

In the Pre-task Phase, teachers have to provide much input and exposure to students, starting with the introduction of the topic, and then giving the reading or listening as the linguistic input. The task goals are set after that, with clear procedure or mechanism of sequencing actions in series of interactions that students will do in the main task phase. In this phase, the task is not set, so the interaction for task doing does not occur; students are more passive in interaction but still active in perceiving the comprehensive input. Teachers, therefore, are more active in modeling and talking, so their task is to provide exposure or input and then set the task in more friendly and understandable way. With the first role, giving input, teachers may use L1 with some difficult grammatical patterns and concepts in English that do not occur in students' first language, may use short 
translation with some abstract lexical items for ease of time-saving and correct understanding of students. Another way of using L1 is to compare the target language with the mother tongue for students' awareness of the grammatical differences. With the second role as a task setter, teachers may guide students by English and then ask students' to repeat the task requirements in their mother tongue to make sure that the task is set correctly. This act is really important since it directs the whole interaction process and affects the outcomes.

In the Task Cycle Phase, students are most active in interactions for task doing in this phase, so they are more dominant language users in class; teachers are only observers, facilitators and supervisors in this phase with less participation in talking, leading and controlling. However, teachers must always be ready for any call for help from students with any insufficiencies of their linguistic input or strategies. Anton \& DiCamilla (1998) states that L1 plays a scaffolding role in collaborative tasks. Students may lack of some key words for the communication of problem-solving task; it is teachers' task to aid them. When supporting students, teachers may sometimes use L1 if the lexical or grammatical concepts are challenging to their understanding. Any quick comprehension check of the concepts of students can be done in L1 for the convenience of correctness and for task progress keeping. More generally, this phase may need least L1 in comparison to the whole cycle.

In the Post-Task Phase, the checking task in the whole class, feedbacks and comments from teachers are required. Maybe, lots of this time, teachers' talking can be in L1 for the sake of learning from errors of students because students must know what exactly their mistakes and errors are before they learn from and make changes in later times. The main task of this phase is to help students consolidate of what they have learned in both language knowledge and skills by analysis activities and by further practices. Storch and Wigglesworth (2003) argues that L1 can be a source of cognitive support for students' language analysis and performing higher level work. An explanation in the mother tongue with highlighted language items can provide useful reinforcement of structural, conceptual, and sociolinguistic differences between the native and the target languages (Atkinson, 1987; Auerbach, 1993; Seidlhofer, 1999). The mother tongue can be used to check students' understanding of the concept behind a structure, e.g. How do you say 'I wish I could learn English better' in Vietnamese? This technique encourages students to develop the ability to distinguish between 'structural, semantic and pragmatic' equivalence (Widdowson, 1974).

\section{Conclusion}

Using the mother tongue in the classroom should no longer be viewed as having drawbacks. Instead, it can be considered as a teaching strategy in conveying meaning across more effectively and efficiently. Cook (2001) believes that teachers who manage to do this can serve as a model of successful bilingual. They are able to use the two languages effectively since each language, either the mother tongue or the target language, serves a different function in the teaching and learning process. In my opinion, English language teaching in Vietnam should not devalue the mother tongue. After all, the ways in which classroom discourse is influenced by the social community outside will constantly remind us that we cannot isolate the classroom from the society in which it is situated. However, the paper does not launch the use of L1 in ELT classrooms, but the argumentation of the unavoidability of this, even in TBLT model. The matter is that teachers have to be sure about the efficiencies of L1 in specific cases, and know how to use it properly to enable their students to reach learning goals. Remember that the overuse of L1 is dangerous to students' interactions and learning.

\section{Notes}

1. The series of new textbooks of English for secondary schools passed by Ministry of Education and Training (MOET) and officially implemented in 2006 in the direction of both language teaching method and curriculum innovation adopted task-based syllabus design, CLT and TBLT and learner-centeredness approach. Nevertheless, from that time when series of new textbooks of English was in use, few researches have been done to investigate how teachers apply TBLT in their classrooms. The author has carried out a research project on investigating secondary school teachers' beliefs and perceptions of teaching method - TBLT and the new textbooks.

\section{Acknowledgments}

I would like to appreciate the enthusiastic efforts from Prof. Dr. Hoang Van Van, Associate Prof. Dr. Le Hung Tien and Dr. Le Van Canh at University of Languages and International Studies - Vietnam National University, Hanoi for their help and encouragements in my study. It is also they whose help me with ideas and comments on my work and hearten me to publish internationally.

\section{References}

Anton, M., \& DiCamila, F. (1998). Socio-cognitive functions of L1 collaborative interaction in the L2 classroom. 
Canadian Modern Language Review, 54, 314-342. http://dx.doi.org/10.3138/cmlr.54.3.314

Atkinson, D. (1987). The mother tongue in the classroom: a neglected resource? ELT Journal, 41(4), 241-247. http://dx.doi.org/10.1093/elt/41.4.241

Auerbach, E. R. (1993). Reexamining English only in the ESL classroom. TESOL Quarterly, 27, 9-32. http://dx.doi.org/10.2307/3586949

Brown, H. D. (2001). Teaching by Principles. An Interactive Approach to Language Pedagogy ( ${ }^{\text {nd }}$ ed.). Addison Wesley, USA: Longman.

Burden, P. (2000). The use of 'only English' in a learner-centred university classroom in Japan. RELC Journal, 31, 139-149. http://dx.doi.org/10.1177/003368820003100107

Bygate, M. (2001). Effects of task repetition on the structure and control of oral language. In M. Bygate, P. Skehan, \& M. Swain (Eds.), Researching pedagogic tasks: second language learning and testing. Harlow, England: Longman Education.

Canh, L. V. (2001). Language and Vietnamese pedagogical contexts. Teacher's Edition, 7, 34-40.

Carless, D. (2003). Factors in the implementation of task-based teaching in primary schools. System, 31, 485-500. http://dx.doi.org/10.1016/j.system.2003.03.002

Carless, D. (2007). The suitability of task-based approaches for secondary schools: Perspectives from Hong Kong. System, 35, 595-608. http://dx.doi.org/10.1016/j.system.2007.09.003

Cook, V. (2001). Using the First Language in the Classroom. Canadian Modern Language Review, 57(3), 402. http://dx.doi.org/10.3138/cmlr.57.3.402

Cross, D. (1995). A Practical Handbook of Language Teaching. Inter Book Distributors Ltd.

Crookes, G., \& Gass, S. (1993). Tasks and language learning: Integrating theory and practice. Clevedon, England: Multilingual Matters.

Ellis, R. (2000). Task-based research and language pedagogy. Language Teaching Research, 4, 193-220. http://dx.doi.org/10.1177/136216880000400302

Ellis, R. (2003). Task-based language teaching and learning. Oxford, UK: Oxford University Press.

Ellis, R. (2005). Planning and task-based performance: Theory and research. In R. Ellis (Ed.), Planning and task performance in a second language (pp. 3-34). Amsterdam, Netherlands: John Benjamins.

Frost, R. (2006, December 4). A Task-based Approach. British Council Teaching English. Retrieved September 22, 2007 from, http://www.teachingenglish.org.uk/think/methodology/task_based.shtml

Gatenby, E. V. (1965). Conditions for success in language learning. In Allen (Ed.), Teaching English as a Second Language: A Book of Readings (pp. 9-14). New York, USA: McGraw-Hill.

Harbord, J. (1992). The use of the mother tongue in the classroom. ELT Journal, 46(4), 350-355. http://dx.doi.org/10.1093/elt/46.4.350

Johnson, K. (1996). Language Teaching and Skill Learning. Oxford, UK: Blackwell.

Lee. J. (2000). Tasks and Communicating in Language Classrooms. Boston, USA: McGraw-Hill.

Lightbown, P. M., \& Spada, N. (1999). How Languages are Learned ( $2^{\text {nd }}$ Ed.). Oxford, UK: Oxford University Press.

Littlewood, W. (2004). The Task-Based approach: Some Questions and Suggestions. ELT Journal, 58(4), 319. http://dx.doi.org/10.1093/elt/58.4.319

Littlewood, W. (2007). Communicative and task-based language teaching in East Asian classrooms. Language Teaching, 40, 243-249. http://dx.doi.org/10.1017/S0261444807004363

Long, M. (1985). A role for Instruction in Second Language Acquisition: Task-Based Language Teaching. In K. Hystelstam, \& M. Pienemann (Eds.), Modeling and accessing Second Language Acquisition. Cleverdon, UK: Multilingual Matters.

Long, M. (1991). Focus on form: A design feature in language teaching methodology. In K. de Bot, R. Ginsburg, \& C. Kramsch S (Eds.), Foreign Language research in cross-cultural perspectives (pp. 39-52). Amsterdam, Netherlands: John Benjamin.

Long, M. (1997). Focus on Form in Task-Based Language Teaching. Fourth Annual. McGraw-Hill Satellite 
Teleconference. Retrieve from http://www.mhhe.com/socscience/foreignlang/top/htm

Long, M. (2005, September). TBLT: Building the road as we travel. Plenary address delivered at the International Conference on Task-based Language Teaching. Leuven, Belgium. pp. 21-23.

Marian, V., Spivey, M., \& Hirsch, J. (2003). Shared and separate systems in bilingual language processing: Converging evidence from eye tracking and brain imaging. Brain and Language, 86, 70-82. http://dx.doi.org/10.1016/S0093-934X(02)00535-7

Marian, V., \& Spivey, M. (2003). Competing activation in bilingual language processing. Bilingualism: Language and Cognition, 6, 97-115. http://dx.doi.org/10.1017/S1366728903001068

Nunan, D. (1989). Designing tasks for communicative language. Cambridge: CUP.

Nunan, D. (1992). Socio-cultural aspects of second language acquisition. Cross Currents, 19, 13-24.

Nunan, D. (1995). Language Teaching Methodology. A Textbook for teachers. Prentice Hall Europe.

Nunan, D. (1999). Second language teaching and learning. Boston, MA: Heinle \& Heinle.

Nunan, D. (2003). Task-Based Language Teaching. Cambridge, UK: Cambridge University Press.

Nunan, D. (2004). Task-based language teaching. Cambridge, UK: Cambridge University Press.

Paradis, J. (2004). The relevance of specific language impairment in understanding the role of transfer in second language acquisition. Applied Psycholinguistics, 25, 67-82. http://dx.doi.org/10.1017/S0142716404001043

Pham, H. H. (2001). A second look at the question of the ownership of English. Teacher's Edition, 7(4), 10.

Phan, L. H. (2008). Teaching English as an international language: Identity, resistance and negotiation. Clevedon, UK: Multilingual Matters.

Phillipson, R. H. L. (1992). Linguistic Imperialism. Oxford: Oxford University Press.

Polio, C. G., \& Duff, P. A. (1994). Teachers' language use in university foreign language classrooms: a qualitative analysis of English and target language situation. The Modern Language Journal, 78, 313-326. http://dx.doi.org/10.1111/j.1540-4781.1994.tb02045.x

Prabhu, N. S. (1987). Second language pedagogy. Oxford: Oxford University Press.

Richard, J. C., \& Rodgers, T. S. (2001). Approaches and Methods in Language Teaching ( $2^{\text {nd }}$ Ed.). Cambridge, UK: Cambridge University Press.

Salaberry, R. (2001). Task-sequencing in L2 acquisition. Texas Papers in Foreign Language Education, 6(1), 101-112.

Seidlhofer, B. (1999). Double standards: teacher education in the Expanding Circle. World Englishes, 18(2), 233-244.

Skehan, P. (1996). A framework for implementation of task-based instructions. Applied Linguistics, 17, 38-62. http://dx.doi.org/10.1093/applin/17.1.38

Skehan, P. (1998a). Task-based instruction. Annual Review of Applied Linguistics, 18, 268-286. http://dx.doi.org/10.1017/S0267190500003585

Skehan, P. (1998b). A cognitive approach to language learning. Oxford, UK: Oxford University Press.

Skehan, P. (2003). Task-Based Instruction. Cambridge, UK: Cambridge University Press.

Storch, N., \& Wigglesworth, G. (2003). Is there a role for the use of L1 in an L2 setting? TESOL Quarterly, 37(4), 760-769. http://dx.doi.org/10.2307/3588224

Swain, M., \& Lapkin, S. (1998). Interaction and second language learning: Two adolescent French immersion students working together. Modem Language Journal, 83, 320-237. http://dx.doi.org/10.1111/j.1540-4781.1998.tb01209.x

Tang, J. (2002). Using L1 in the English classroom. English Teaching Forum, 40(1), 36-43. Retrieved August 10, 2007 from, http://exchanges.state.gov/forum/vols/vol40/no1/p36.htm\#top

Wells, G. (1999). Using L1 to master L2: A response to Anton and DiCamilla's "Sociocognitive functions of L1 collaborative interaction in the L2 classroom". The Modern Language Journal, 83(2), 248-254. http://dx.doi.org/10.1111/0026-7902.00019

Widdowson, H. G. (1974). The deep structure of discourse and the use of translation. In C.J Brumfit, \& K. 
Johnson (Eds.), The Communicative Approach to Language Teaching. Oxford, UK: Oxford University Press.

Willis, J. (1996). A Framework for Task-Based Learning. Harlow, Essex: Addison Wesley Longman. Longman.

Willis, J. (1998). Task-based learning? What kind of adventure? Retrieved April 22, 2005 from, http://langue.hyper.chubu.ac/jp/jalt/pub/tlt/98/jul/willis.html

Willis, D., \& Willis J. (2001). Task-based language learning. In R. Carter, \& D. Nunan (Eds.), The Cambridge Guide to Teaching English to Speakers of Other Languages. Cambridge, UK: Cambridge University Press. 